\title{
Artisanal fisheries in a Brazilian hypereutrophic reservoir: Barra Bonita Reservoir, Middle Tietê River
}

\author{
Novaes JLC. ${ }^{a *}$ and Carvalho ED. ${ }^{b *}$ \\ aDepartamento de Ciências Animais, Universidade Federal Rural do Semi-Árido - UFERSA, \\ BR 110, Km 47, Costa e Silva, CEP 59625-900, Mossoró, RN, Brazil

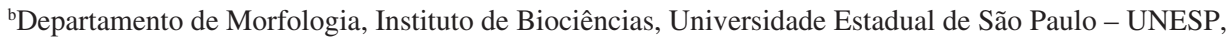 \\ Distrito de Rubião Jr., CEP 18618-970, Botucatu, SP, Brazil \\ *e-mail: carvalho@ibb.unesp.br; novaes@ufersa.edu.br
}

Received June 25, 2010 - Accepted December 23, 2010 - Distributed November 30, 2011

(With 2 figures)

\begin{abstract}
This study examines the qualitative and quantitative aspects of fishery landings at the hypereutrophic Barra Bonita reservoir, Brazil. Data were collected each month (July/2004-June/2006) at three localities and the reported catch, fishing effort and fishing techniques were recorded from 745 landings, comprising a total fish catch of 86,691.9 kg. The most caught species were exotic tilapias, especially the Nile tilapia (Oreochromis niloticus L.), which represented $82.5 \%$ of the total biomass. The reservoir's fishery productivity was $11.1 \mathrm{~kg} / \mathrm{ha}^{-1} / \mathrm{day}^{-1}$ with a Catch Per Unit Effort of $62.4 \mathrm{~kg} / \mathrm{fisher}^{-1} / \mathrm{day}^{-1}$. Five fishing techniques were identified: cast net, gill net, trawl net, beating gill net, and beating gill net + gill net. The analysis of DCA related the active strategies for the tilapia catch, to the passive strategies for the Pimelodus maculatus (Lacepède) and Triportheus angulatus catches (Spix \& Agassiz), and the mixed strategies for the tilapia, catfish and Prochilodus lineatus (Valenciennes) catches. ANCOVA results were significant for all the variables analysed (season, fishing location and fishing technique). The results showed that fishing for "corvina" Plagioscion squamosissimus (Heckel), predominant in the 1990s, had been replaced by fishing focused on the Nile tilapia. This substitution appears to be due to the increasing levels of eutrophication in the reservoir, combined with changes in fishing techniques. The pattern of the fisheries in Barra Bonita Reservoir follow those in other eutrophic Brazilian reservoirs, with catches of the exotic Nile tilapia predominating.
\end{abstract}

Keywords: eutrophic, Oreochromis niloticus, small-scale fisheries, exotic species, fishing strategies.

\section{Pesca artesanal em um reservatório hipertrófico brasileiro: reservatório de Barra Bonita, médio rio Tietê}

\begin{abstract}
Resumo
Esse estudo avaliou aspectos quantitativos qualitativos do desembarque pesqueiro no reservatório hipertrófico de Barra Bonita. Os dados foram coletados mensalmente (julho/2004-junho/2006) em três localidades e informações sobre captura, esforço de pesca e técnicas de pesca foram registrados de 745 desembarques, totalizando $86.691,9 \mathrm{~kg}$ de pescado capturados. As espécies mais capturadas foram as exóticas tilápias, especialmente a tilápia-do-nilo (Oreochromis niloticus L.), que representaram 82,5\% da biomassa total. A produtividade pesqueira do reservatório foi de $11,1 \mathrm{~kg} / \mathrm{ha}^{-1} / \mathrm{dia}^{-1}$ com uma Captura Por Unidade de Esforço de 62,4 kg/pescador ${ }^{-1} / \mathrm{dia}^{-1}$. Cinco técnicas de pesca foram identificadas: tarrafas, rede de espera, rede de arrasto, pesca da batida e pesca da batida + rede de espera. Análise de DCA relacionou as estratégias ativas com a captura de tilápia, as estratégias passivas com a captura de Pimelodus maculatus (Lacepède) e Triporthues angulatus (Spix \& Agassiz) e a estratégia mista com a captura de tilápia, cascudos e Prochilodus lineatus (Valenciennes). Os resultados da ANCOVA foram significativos para todas as variáveis analisadas (época, local de pesca e técnicas de pesca). Os resultados mostram uma substituição da pesca da corvina, Plagioscion squamossisimus (Heckel) na década de 1990, pela tilápia-do-nilo. A substituição pode ter sido provocada pelo aumento da eutrofização do reservatório, aliado à mudança das estratégias de pesca. A pesca no reservatório de Barra Bonita seguiu padrões de outros reservatórios eutrofizados brasileiros, com a pesca sustentada pela exótica tilápia-do-nilo.
\end{abstract}

Palavras-chave: eutrofização, Oreochromis niloticus, pesca de pequena escala, espécie exótica, estratégias de pesca. 


\section{Introduction}

Inland artisanal fisheries in Brazil are common in rivers, flood plains, artificial reservoirs, and dam (Petrere Junior, 1996). Artisanal fisheries in reservoirs range widely in size and are often poorly organised and under complex and contradictory government legislation and inspection. These problems, and the shortage and inconsistency of data on artisanal fisheries in Brazilian reservoirs, have been well summarised by Agostinho et al.(2007, 2008).

Some Brazilian reservoirs, especially those in the south and southeast, have suffered from gradual eutrophication due to factors such as growing regional industrialisation, accelerated and unplanned urban growth, and run-off of fertilizer from increasingly intensive farming systems (Agostinho et al., 2005). Another impact on these reservoirs, especially in the 1970s and 1980s, has been the stocking of allochthonous/exotic species with the objective of improving fishery productivity. Massive stocking programmes in reservoirs in the state of São Paulo were associated with the building of hydro-electric power programmes. Stocking was primarily with Plagioscion squamosissimus ("corvina"), Cichla spp. ("tucunaré"), both from the Amazon Basin, and Oreochromis niloticus (Nile tilapia) from Africa (CESP, 1998). However, these stocking programmes failed in most reservoirs and the introduced species did not become established as well as expected (Carvalho et al., 2005). In the Barra Bonita reservoir, some exotic species, mainly Nile tilapia and corvina, did establish self-sustaining populations (Eco, 2001; Petesse et al., 2007).

Previous studies of artisanal fisheries in small Brazilian eutrophic reservoirs include: Paiva et al.(1994) dam in the northeast; Minte-Vera and Petrere Junior (2000) in the Billings Reservoir (metropolitan region of São Paulo); Alvares et al.(2000) in Pampulha Lagoon (Belo Horizonte City); and Walter and Petrere Junior (2007) in the Paranoá Lake (Brasilia). These studies showed that these reservoirs have high fish production and that fishing is supported by the exotic Nile tilapia.

The aim of this study was to evaluate the artisanal fisheries in the hypereutrophic Barra Bonita Reservoir in southeast Brazil, particularly focusing on: i) the qualitative and quantitative analysis of the fish species landed; and ii) the fishing techniques used in the reservoir. We hypothesise that the progressive increase in eutrophication of the Barra Bonita Reservoir in recent decades has led to changes in the artisanal fisheries and the spread of species able to thrive in eutrophic environments.

\section{Material and Methods}

\subsection{Study area}

The Barra Bonita Reservoir (22 $31^{\prime}$ 10.2” S and $48^{\circ} 32^{\prime}$ 03” W) was created in 1963, the Tietê and Piracicaba Rivers being the main rivers tributaries (Figure 1). The Tietê River runs for $1136 \mathrm{~km}$, draining an area of $71,988 \mathrm{~km}^{2}$ and, even in its upper course, receives significant quantities of effluent, especially fresh household waste, estimated at about 130 tons of organic and inorganic waste daily (Ferraz, 2002). After leaving the metropolitan region of São Paulo, the Tietê River runs about $250 \mathrm{~km}$ further to the Barra Bonita Reservoir. In this stretch, the river has small waterfalls and rapids, which oxygenate the water and result in a slight improvement in its quality (Barrella and Petrere Junior, 2003). The Piracicaba River, the other tributary of the reservoir, also receives untreated domestic sewage, though in lesser quantities than the Tietê River. Because of the large amount of untreated sewage discharged into the Barra Bonita Reservoir by its tributary rivers, it has been classified as hypereutrophic since 2000 (Straškraba and Tundisi, 2000; Tundisi et al., 2008).

\subsection{Data collection}

The number of fishermen operating in the Barra Bonita Reservoir is uncertain, but it is estimated at about 450 (David et al., 2006; Maruyama et al., 2009). These fishers operate around the reservoir banks, from small, disordered and diffuse groups of shacks and camps without any kind of urban infrastructure, water treatment, sewage system, or garbage collection, making accurate statistical surveys on fish landings from the reservoir difficult to achieve.

Sample data were collected at three representative landing sites: Rio Bonito, Anhembi and Santa Maria da Serra (Figure 1), from which 243 fishers operated. At first, we tried to set up a voluntary system whereby fishers filled out forms recording their catches, but without success. Sample data therefore had to be collected by field observers who visited the three sampling sites around the $15^{\text {th }}$ day of each month, between July 2004 and June 2006. The data collectors arrived at the landing places before the arrival of the fishers, in the afternoon at Rio Bonito and Anhembi, and in the morning at Ponte Santa Maria da Serra, to coincide with the majority of the fish landings at each site. When the fishers arrived, the fish catches were weighed (in $\mathrm{kg}$ ) and the fishers interviewed using a standard form to collect information about catch, fishing effort, and the apparatus and fishing locations used.

For the qualitative and quantitative analyses, fish were grouped into the following categories: 1) "tilapia": Oreochromis niloticus and Tilapia rendalli (Boulenger); 2) "cascudo" (catfish): Pterygoplichthys anisitsi Eigenmann \& Kennedy and Hypostomus spp.; 3) "mandi" (catfish): Pimelodus maculates; 4) "curimbatá": Prochilodus lineatus; 5) "sardinha": Triportheus angulatus; and 6) other fish. The weights of "cascudos" landed in filleted form and "tilapia" in the form called "porquinho" (without viscera, head, and dorsal and anal fins) were corrected to estimate their gross weight at capture following the methods of Silvano and Begossi (2001) and Minte-Vera and Pretrere Junior (2000). For the analysis of seasonal effects, months were grouped into winter (July, August, September), spring (October, November, December), summer (January, February, March) and autumn (April, May, June). 


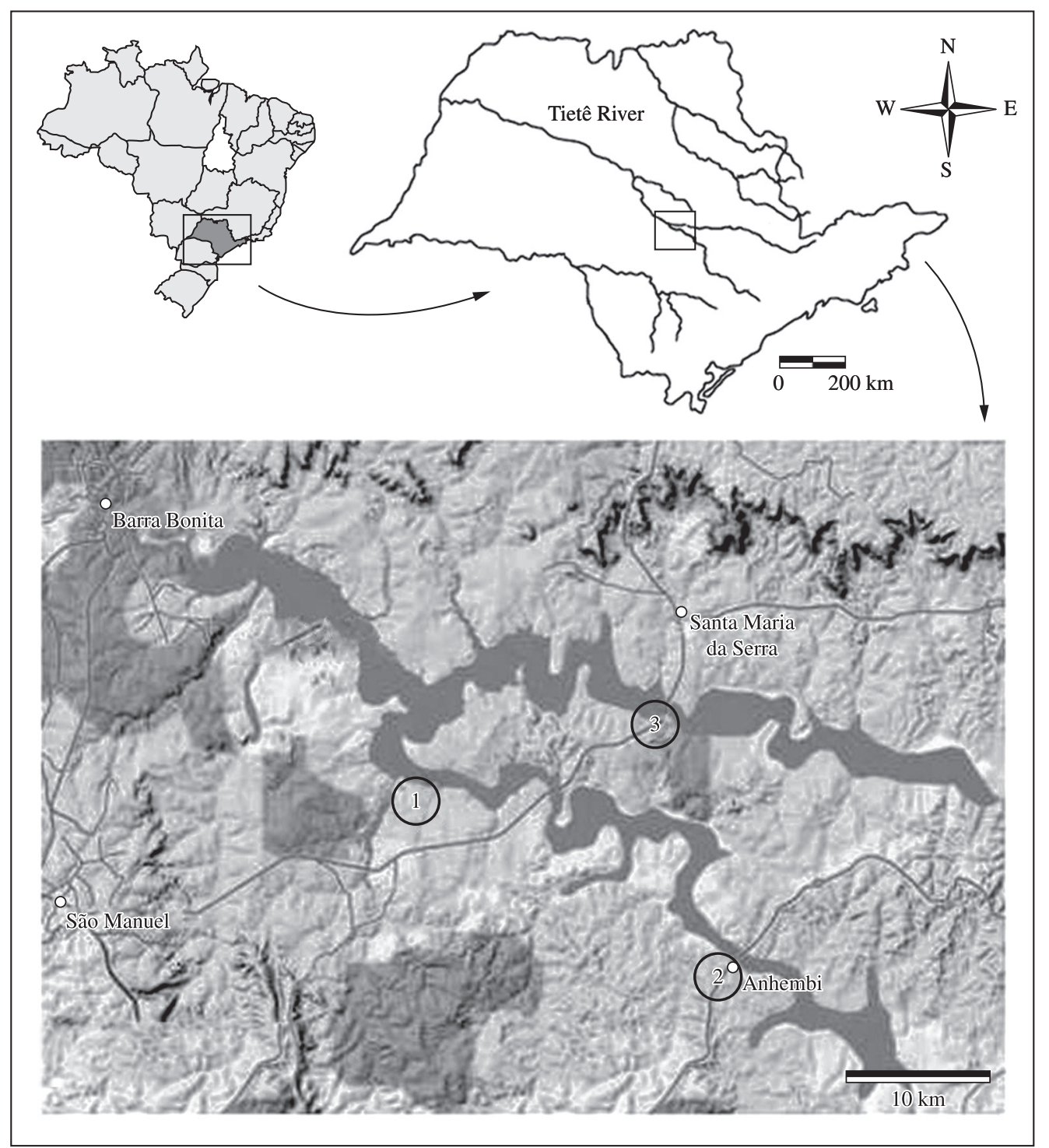

Figure 1. Location of Barra Bonita Reservoir with sampling sites: 1) Rio Bonito, 2) Anhembi and 3) Santa Maria da Serra (modified from Google Earth).

\subsection{Catch per unit effort (CPUE)}

Before expressing the data as CPUE, it was verified that the catch $(\mathrm{C})$ and effort (f) data satisfied a linear relationship with the regression of $\mathrm{Cxf}$ passing through the origin (Petrere Junior et al., 2010). A $\log _{10}$ conversion of catch $(\mathrm{C})$ and $\mathrm{f}$ (fishers/day) gave a statistically significant linear regression $\left(\operatorname{Clog}_{10}=1.0083 f \log _{10}+1.763 ; \mathrm{r}^{2}=0.6392\right.$; $\mathrm{p}<0.0001$ ) with an intercept not significantly different from zero $(p=0.5382)$. We can therefore assume that this represents a true CPUE measure. The CPUE was estimated by C/f: where $\mathrm{C}=\mathrm{S} C i j \sum C i j$, where $C i j=$ the catch by $j$ number of fishers on day $i$; and $\mathrm{f}=\mathrm{S} \mathrm{fij} \sum f i j$, where $f i j=$ observed effort by $j$ number of fishers on day $i$. Thus, the CPUE was expressed in $\mathrm{kg} / \mathrm{fisher}^{-1} / \mathrm{day}^{-1}$. Values for
CPUE were compared with results from other reservoirs published in the literature.

\subsection{Statistical analysis}

An analysis of covariance (ANCOVA), a statistical method that combines regression analysis with analysis of variance (Quinn and Keough, 2002), was performed on the catch (response variable) and effort data looking for possible factors affecting the catch (Pereira et al., 2008). In order to balance the model and reduce environmental noise (Petrere Junior, 1978), data were grouped by season, fishing location, and fishing technique (factors). Test of normality $\left(g_{1}-\right.$ coefficient of asymmetry and $g_{2}-$ coefficient of kurtosis) was carried out in order to validate the model. 
The model components were (Equation 1):

$Y_{I J K}=m+a_{I}+p_{J}+g_{K}+b\left(X_{I J K}-X^{\prime}\right)+E_{I J K}$

where: $Y_{I J K}=$ response variable $\left(\log _{10}\right.$ of catch $)$; = overall mean; $a_{I}=$ season (winter, spring, Summer, autumn); $p_{J}=$ fishing location (Anhembi, Ponte Santa Maria da Serra e Porto Said); $g_{K}=$ fishing technique (trawl net, cast net, beating gill net, gill net, combination gill net and beating gill net); $b=$ linear effect of the covariate; $X_{I J K}=$ covariate $\left(\log _{10}\right.$ of fishing effort, expressed in fishers per day); $X^{\prime}=$ mean covariate effort; $E_{I J K}=$ random error component.

Furthermore, a multiple comparison test a posteriori of Tukey HSD was employed to detect significant differences between pairs of adjusted means $(\mathrm{p}<0.05)$.

To evaluate the fish catch associated with the different fishing strategies (trawl net, cast net, beating gill net, gill net and gill net and beating gill net), a Detrended Correspondence Analysis (DCA) was applied, with the effect of arc removed (Ludwig and Reynolds, 1988). For the interpretation of the DCA, dimensions of up to $95 \%$ of the total explanation of inertia were extracted (Mingote, 2005).

\section{Results}

\subsection{Composition of fishing, landing, catch and effort}

Thirty-three species were recorded in all of the 745 fish landing records, of which 7 were introduced (allochthonous or exotic) (Table 1). A total of $86,691.9 \mathrm{~kg}$ of landed fish were recorded, with an average yield of $116.3 \mathrm{~kg} /$ trip $(\mathrm{N}=745$; $\mathrm{SD}=107.1)$. "Tilapias" were the most representative caught species by weight, totalling $71,513.5 \mathrm{~kg}$, and corresponding to $82.5 \%$ of the total biomass landed. Nile tilapia accounted for $98 \%$ of the total "tilapias" caught. "Cascudos" were the second most-caught fish by weight at $6,151.6 \mathrm{~kg}$ total $(7.1 \%$ of the total biomass landed). Other important species landed were "mandi" $(3,020.3 \mathrm{~kg}-3.5 \%)$, "sardinha" $(2,214.7 \mathrm{~kg}-2.6 \%)$, and "curimbatá" $(1,650.6 \mathrm{~kg}-1.9 \%)$. These five types of fish represented for $97.6 \%$ of the total biomass landed by this artisanal fishery in the three locations studied. The estimated average CPUE was $51.5(\mathrm{SD}=54.3)$ and $1.2(\mathrm{SD}=4.7) \mathrm{kg} /$ fisher $^{-1} / \mathrm{day}^{-1}$ for "tilapias" and "curimbatá", respectively, compared to the average total CPUE for all species in the reservoir, estimated at $62.4 \mathrm{~kg} /$ fisher $^{-1} /$ day $^{-1}$ $(\mathrm{SD}=55.4)$. The productivity of the entire fishery was estimated at $11.11 \mathrm{~kg} / \mathrm{ha}^{-1} / \mathrm{day}^{-1}$ compared to that of the main fish at 9.2 and $0.2 \mathrm{~kg} / \mathrm{ha}^{-1} / \mathrm{day}^{-1}$ for "tilapia" and "curimbatá", respectively (Table 2 ).

Tilapias were the predominant species landed in all three locations, but had different CPUE values and relative frequency of occurrence at each. At Rio Bonito, only "tilapias" were landed, with a biomass of 43,234.5 kg (100\%) and an estimated average CPUE of $69.0 \mathrm{~kg} / \mathrm{fisher}^{-1} / \mathrm{day}^{-1}$ ( $\mathrm{SD}=60.6)$. At Anhembi, the total biomass landed was $31,687.5 \mathrm{~kg}$, of which $23,715 \mathrm{~kg}(74.8 \%)$ were "tilapias",
$5,821.4 \mathrm{~kg}(18.4 \%)$ were "cascudo", and 1,505.5 kg (4.8\%) were "curimbatá". The estimated average CPUE was $53.7 \mathrm{~kg} /$ fisher $^{-1} /$ day $^{-1}$ (SD = 45.9), $13.1 \mathrm{~kg} /$ fisher $^{-1} /$ $\operatorname{day}^{-1}(\mathrm{SD}=24.7)$ and $3.4 \mathrm{~kg} /$ fisher $^{-1} / \mathrm{day}^{-1}(\mathrm{SD}=7.3)$ for "tilapias", "cascudo" and "curimbatá", respectively. At Ponte Santa Maria da Serra, the total biomass landed was $11,769.9 \mathrm{~kg}$, of which $4,729 \mathrm{~kg}(40.2 \%)$ were tilapias with an estimated average CPUE of $14.8 \mathrm{~kg} /$ fisher $^{-1}$ / $\operatorname{day}^{-1}(\mathrm{SD}=32.1), 3,000.5 \mathrm{~kg}(22.5 \%)$ were mandi with an estimated average CPUE of $9.4 \mathrm{~kg} / \mathrm{fisher}^{-1} / \mathrm{day}^{-1}(\mathrm{SD}=$ $14.0)$ and $2,177.0 \mathrm{~kg}(18.5 \%)$ were "sardinha" with an estimated average CPUE of $6.8 \mathrm{~kg} / \mathrm{fisher}^{-1} / \mathrm{day}^{-1}(\mathrm{SD}=$ 21.3) (Tables 3a and 3b).

\subsection{Fishing strategies}

Five fishing techniques are used in this artisanal fishery: trawl net, cast net, beating gill net (active techniques); gill net (passive technique); and gill net and beating gill net (mixed technique). i) Trawl net: This is a net $150 \mathrm{~m}$ long with a mesh from 9 to $12 \mathrm{~cm}$ between opposing knots, used by two fishers to surround an area of water. The net is usually operated by two ropes fixed to its ends, used for hauling the net in and for herding the fish. Target species, Nile tilapia; ii) Beating gill net: Two fishers use three or four gill nets, each $50 \mathrm{~m}$ long with mesh $10 \mathrm{~cm}$ between opposing knots, while a fisher drives a boat and another beats the water with a wooden rod to drive the fish and increase their likelihood of getting caught in the net. Target species, Nile tilapia; iii) Cast net: One fisher casts a net with a mesh $9 \mathrm{~cm}$ between opposing knots, so as to catch fish within the falling net. Target species, Nile tilapia; iv) Gill net: Usually two fishers use a net to catch, entangle or enmesh fish in the net by their gills. These nets are fixed to the reservoir bottom, or at certain distance above it, depending on the fish species targeted. Four or five nets, each $35 \mathrm{~m}$ long, are tied together to form a set and fishers operate from eight to ten sets of nets at a time, putting them into the water at 4:00 PM and removing them at 5:00 AM the following morning. The mesh size varies according to the target species: $2-3 \mathrm{~cm}$ between opposing knots to catch "lambaris", $5 \mathrm{~cm}$ between opposing knots to catch "sardinha", and 8, 9 and $10 \mathrm{~cm}$ between opposing knots to catch Nile tilapia, "corvina", "mandi", "cascudo" and "curimatã"; v) Gill net and beating gill net: A combination of the two techniques described above. Target species, Nile tilapia, "cascudo and "curimbatá".

The frequency of use of these techniques varied between locations. At Rio Bonito, the techniques employed were; trawl net $(73.9 \%)$, combination of gill net and beating gill net $(20.7 \%)$, and beating gill net $(5.4 \%)$. At Anhembi the techniques were: Cast net (36.5\%), combination of gill net and beating gill net (36.2\%), and beating gill net (26.2\%). At Ponte Santa Maria da Serra, $100 \%$ of the fishing trips used the gill net technique (Table 4). 
Table 1. List of fish species caught by artisanal fisheries in the Barra Bonita Reservoir (Middle Tietê River) during the study period.

\begin{tabular}{|c|c|}
\hline Taxon & Common name \\
\hline \multicolumn{2}{|l|}{ CHARACIFORMES } \\
\hline \multicolumn{2}{|l|}{ Anostomidae } \\
\hline Leporinus friderici (Bloch, 1974) & Piava, piau \\
\hline Leporinus obtusidens (Valenciennes, 1837) & Piava, piau \\
\hline Leporinus elongatus Valenciennes, 1850 & Piava, piau \\
\hline Schizodon intermedius Garavello \& Britski, 1990 & Piapara, ximborê \\
\hline \multicolumn{2}{|l|}{ Characidae } \\
\hline Astyanax altiparanae Garutti \& Britski, 2000 & Lambari \\
\hline Astyanax fasciatum (Cuvier, 1819) & Lambari \\
\hline Salminus brasiliensis (Cuvier, 1816) & Dourado \\
\hline Salminus hilarii Valenciennes, 1850 & Tabarana \\
\hline Serrasalmus maculatus Kner, 1858 & Piranha \\
\hline Piaractus mesopotamicus (Holmberg, 1887) & Pacu \\
\hline Triportheus angulatus* (Spix \& Agassiz, 1829) & Sardinha, sardela \\
\hline Galeocharax knerii (Steindachner, 1879) & Cadela \\
\hline \multicolumn{2}{|l|}{ Parodontidae } \\
\hline Apareiodon piracicabae (Eigenmann, 1907) & Canivete \\
\hline \multicolumn{2}{|l|}{ Curimatidae } \\
\hline Cyphocharax modestus (Fernández-Yépez, 1948) & Saguirú \\
\hline Steindachinerina insculpta (Fernández-Yépez, 1948) & Saguirú \\
\hline \multicolumn{2}{|l|}{ Erythrinidae } \\
\hline Hoplias aff. malabaricus (Bloch, 1794) & Traíra \\
\hline \multicolumn{2}{|l|}{ Prochilodontidae } \\
\hline Prochilodus lineatus (Valenciennes, 1836) & Curimatá \\
\hline \multicolumn{2}{|l|}{ SILURIFORMES } \\
\hline \multicolumn{2}{|l|}{ Callichthyidae } \\
\hline Hoplosternum littorale (Hancock, 1828) & Caborja \\
\hline \multicolumn{2}{|l|}{ Loricariidae } \\
\hline Hypostomus spp. & Cascudo \\
\hline Pterygoplichthyes anisitsi* Eigenmann \& Kennedy, 1903 & Cascudo \\
\hline \multicolumn{2}{|l|}{ Pimelodidae } \\
\hline Pimelodus maculatus La Cepède, 1803 & Mandi \\
\hline \multicolumn{2}{|l|}{ Doradidae } \\
\hline \multicolumn{2}{|l|}{ Rhinodoras cf. dorbignyi (Kner, 1855) } \\
\hline \multicolumn{2}{|l|}{ GYMNOTIFORMES } \\
\hline \multicolumn{2}{|l|}{ Gymnotidae } \\
\hline Gymnotus carapo (Linnaeus, 1758) & Tuvira \\
\hline Eigenmannia sp. & Tuvira \\
\hline \multicolumn{2}{|l|}{ PERCIFORMES } \\
\hline \multicolumn{2}{|l|}{ Cichlidae } \\
\hline Astronotus ocellatus* (Agassiz, 1831) & Oscar \\
\hline Geophagus brasiliensis (Quoy \& Gaimard, 1824) & Cará \\
\hline Crenicichla sp. & Joaninha \\
\hline Oreochromis niloticus* (Linnaeus, 1758) & Nile tilapia \\
\hline Satanoperca sp. & Cará \\
\hline Tilapia rendalli* (Boulenger, 1897) & Tilápia \\
\hline \multicolumn{2}{|l|}{ Sciaenidae } \\
\hline Plagioscion squamosissimus* (Heckel, 1840) & Corvina, pescada \\
\hline \multicolumn{2}{|l|}{ CYPRINIFORMES } \\
\hline \multicolumn{2}{|l|}{ Cyprinidae } \\
\hline Hypophthalmichthys molitrix* (Valenciennes, 1844) & Carpa cabeça grande \\
\hline Hypophthalmichthys nobilis* (Richardson, 1845) & Carpa \\
\hline
\end{tabular}

*Introduced species. 
Table 2. Total biomass (kg), relative frequency (\%), CPUE ( $\left.\mathrm{kg} / \mathrm{fisher}^{-1} / \mathrm{day}^{-1}\right)$ and $\mathrm{kg} / \mathrm{ha}^{-1} / \mathrm{day}^{-1}$ for the main fish caught by artisanal fisheries in the Barra Bonita Reservoir (Middle Tietê River) during the study period.

\begin{tabular}{lcccc}
\hline Fish & Total biomass & \% & CPUE (SD) & $\mathbf{~ k g} / \mathbf{h a}^{-1 / \mathbf{d i a}^{-1}}$ \\
\hline Tilapia & $71,513.5$ & 82.5 & $51.5(54.3)$ & 9.2 \\
Cascudo & $6,151.6$ & 7.1 & $4.4(16.1)$ & 0.8 \\
Curimbatá & $1,650.6$ & 1.9 & $1.2(4.7)$ & 0.2 \\
Mandi & $3,020.3$ & 3.5 & $2.2(7.5)$ & 0.4 \\
Sardinha & $2,214.7$ & 2.6 & $1.6(10.3)$ & 0.3 \\
Others & $2,141.3$ & 2.4 & $1.5(3.5)$ & 0.3 \\
Total & $86,691.9$ & 100.0 & $62.4(55.4)$ & 11.1 \\
\hline
\end{tabular}

Table 3. a) Total biomass (kg) and relative frequency (\%), and b) average values of CPUE (kg/fisher $\left.{ }^{-1} / \mathrm{day}^{-1}\right)$ for localities of fishing for the main fish caught by artisanal fisheries in the Barra Bonita Reservoir (Middle Tietê River) during the study period. $\mathrm{SD}=$ Standard deviation.

\begin{tabular}{|c|c|c|c|}
\hline & Rio Bonito & Anhembi & Santa Maria da Serra \\
\hline Fish & Total biomass $(\%)$ & Total biomass $(\%)$ & Total biomass (\%) \\
\hline \multicolumn{4}{|l|}{ a) } \\
\hline Tilapia & $43,234.5(100)$ & $23,715.0(74.8)$ & $4,729.0(40.2)$ \\
\hline Cascudo & $0.0(0.0)$ & $5821.4(18.4)$ & $200.1(1.7)$ \\
\hline Curimbata & $0.0(0.0)$ & $1505.5(4.8)$ & $145.1(1.2)$ \\
\hline Mandi & $0.0(0.0)$ & $19.8(0.1)$ & $3,000.5(22.5)$ \\
\hline Sardinha & $0.0(0.0)$ & $2.7(0.01)$ & $2,177.0(18.5)$ \\
\hline Others & $0.0(0.0)$ & $623.1(2.3)$ & $1518.2(12.9)$ \\
\hline Total & $43,234.5(100)$ & $31,687,5(100)$ & $11,769.9(100)$ \\
\hline b) & CPUE (SD) & CPUE (SD) & CPUE (SD) \\
\hline Tilapia & $69.0(60.6)$ & $53.7(45.9)$ & $14.8(32.1)$ \\
\hline Cascudo & $0.0(0.0)$ & $13.1(24.7)$ & $0.6(1.6)$ \\
\hline Curimbata & $0.0(0.0)$ & $3.4(7.3)$ & $0.5(2.3)$ \\
\hline Mandi & $0.0(0.0)$ & $0.04(0.3)$ & $9.4(14.0)$ \\
\hline Sardinha & $0.0(0.0)$ & $0.01(0.1)$ & $6.8(21.3)$ \\
\hline Others & $0.0(0.0)$ & $1.4(6.8)$ & $4.0(4.3)$ \\
\hline Total & $69.0(60.6)$ & $71.6(54.7)$ & $36.1(35.3)$ \\
\hline
\end{tabular}

Table 4. Relative frequency of fishing strategy used by fishermen in the three localities fishing in the Barra Bonita Reservoir (Middle Tietê River) during the study period.

\begin{tabular}{lccccc}
\hline $\begin{array}{c}\text { Fishing } \\
\text { strategy }\end{array}$ & $\begin{array}{c}\text { Trawl net } \\
(\boldsymbol{\%})\end{array}$ & $\begin{array}{c}\text { Beating gill } \\
\text { net }(\boldsymbol{\%})\end{array}$ & $\begin{array}{c}\text { Cast net } \\
(\boldsymbol{\%})\end{array}$ & $\begin{array}{c}\text { Gill net } \\
(\boldsymbol{\%})\end{array}$ & $\begin{array}{c}\text { Gill net + Beating } \\
\text { Gill net }(\boldsymbol{\%})\end{array}$ \\
\hline Localities & & & & & \\
$\quad$ Rio Bonito & 73.9 & 5.4 & 0.0 & 0.0 & 20.7 \\
Anhembi & 0.0 & 26.2 & 36.5 & 1.1 & 36.2 \\
Santa Maria da Serra & 0.0 & 00 & 0.0 & 100.0 & 0.0 \\
\hline
\end{tabular}

In the DCA analysis, the first two axes explained $99.9 \%$ of the variation between the fishing strategy used and the biomass of fish caught. The active techniques, trawl net, beating gill net and cast net, were correlated with the catch of "tilapias", while the passive gill net technique was correlated with the catch of "mandi" and "sardinha". The mixed strategy (gill net + beating gill net) correlated with the catch of "tilapias", "catfishes" and "curimbatá" (Figure 2).

\subsection{ANCOVA}

The results of coefficient of asymmetry $\left(\mathrm{g}_{1}=-0.6285 \mathrm{~ns}\right)$ and coefficient of kurtosis $\left(\mathrm{g}_{2}=1.0852 \mathrm{~ns}\right)$ showed that the distribution of the residuals is normal, validate the use 
of an ANCOVA. Table 5 shows the results of the model ANCOVA for the catch data. The covariate (effort) had a significant effect, as did all of the factors. The final ANCOVA model was (Equation 2):

$\log _{10} \mathrm{C}=\mathrm{m}+$ season + fishing technique + fishing location $+\log _{10} f+b$

Table 6 shows the results of an a posteriori Tukey HSD between the factors.

\section{Discussion}

The artisanal fishery at Barra Bonita Reservoir focuses principally on the Nile tilapia, which comprises more than $82 \%$ of the fish biomass caught there. This represents a drastic change in the species composition of the fish in this reservoir compared to the situation in the 1980s and early 1990s, when the "corvina" was the most important fish landed, representing from $50 \%$ to $60 \%$ of total catch by weight, and the Nile tilapia was not present at all (Torloni et al., 1993). By early 2000, the Nile tilapia had become the most caught fish by weight, comprising $25.4 \%$

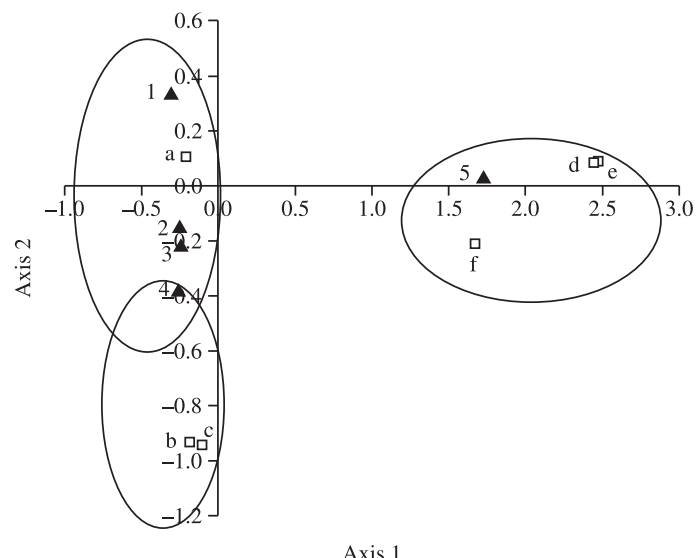

Axis 1

Figure 2. Scores of the first two axes derived of correspondence analysis (DCA) performed from the matrix of the biomass of fish caught for fishing strategies by artisanal fisheries in the Barra Bonita Reservoir (Middle Tietê River) during the study period. Axis $1=84.1 \%$, and Axis $2=15.7 \%$; $\boldsymbol{\Delta}=$ Fishing strategies: 1) Trawl net, 2) Cast net, 3) Beating gill net, 4) Gill net + Beating gill net, 5) Gill net. $\square=$ Fish: a) Tilapia, b) "cascudo", c) Curimbata, d) Mandi catfish, e) Sardinha e f) other fishes. of total catch (Eco, 2001), since when it has grown to the dominance documented in this study. The older fishers from the Barra Bonita Reservoir recall that increased catches of Nile tilapia began between 1998 and 2000, although this appears not to have been reported in the literature.

Various hypotheses have been put forward to explain this substitution of "corvina" by Nile tilapia. i) Agostinho et al. (2007) suggested that the stocking program carried out by the electric power scheme (CESP) during the 1980s, which released 40 thousand juvenile Nile tilapia over an approximately ten year period (CESP, 1998), had no effect on the artisanal fishery. They believe that the current abundance of Nile tilapia is a consequence of their massive and constant escapes from free-fishing farms in the region allowing them to invade, proliferate and establish in the reservoir; ii) The process of artificial eutrophication and the consequent decline in water quality has also been blamed. Limnological studies have shown an increase in eutrophication of the Barra Bonita Reservoir dating from the 1990s (Straškraba and Tundisi 2000; Tundisi et al., 2008). This decline in water quality may have caused the depletion of species with low tolerance to these conditions, such as the allochthonous "corvina". This species is a visual predator (Bennemann et al., 2006), and may have experienced increasing difficulty in hunting as the water transparency decreased, or as its preferred prey, small fishes and aquatic insect larvae, declined as water conditions became less favorable (Bennemann et al., 2006). The Nile tilapia is an opportunistic species, with an exceptional ability to adjust to environmental conditions inhospitable to other species, especially to low concentrations of dissolved oxygen (Lowe-McConnell, 1987; Duponchelle et al., 2000); iii) Changes in fishing techniques may have had an effect. In the 1990s, fishers around the Barra Bonita Reservoir mainly used gill nets to catch fish (Torloni et al., 1993), and focused on "corvina" as the preferred species. However, active fishing techniques such as cast nets, and especially beating gill and trawl nets, are the most effective techniques for catching the Nile tilapia and other Cichlids. The beating gill net has been used successfully at other Brazilian reservoirs to catch Nile tilapia, for example at the Marimbondo Reservoir (Rio Grande, southeast Brazil) (Câmara et al., 1998), and at Billings (Minte-Vera and Petrere Junior, 2000). The trawl net is another active technique used by fishers at Barra Bonita to catch Nile tilapia and is especially effective in the lentic parts of the reservoir. Although the origin of Nile tilapia in the reservoir

Tabela 5. Result of covariance analysis for artisanal fisheries in Barra Bonita reservoir. Factors: season, fishing site and fishing techniques; covariate effort.

\begin{tabular}{lcccrc}
\hline \multicolumn{1}{c}{ Effect } & SS & Degree of freedon & MS & F & p \\
\hline Season & 1.53 & 3 & 0.51 & 3.5 & $0.015^{*}$ \\
Fishing site & 1.03 & 2 & 0.52 & 3.6 & $0.029^{*}$ \\
Fishing techniques & 8.12 & 4 & 2.03 & 14.0 & $0.000^{*}$ \\
Effort & 20.83 & 1 & 20.83 & 143.6 & $0.000^{*}$ \\
\hline
\end{tabular}

*level significance $\mathrm{p}<0.05$. 
Tabela 6. Mean $\left(\log _{10}\right)$, standard error and result of post hoc test Tukey HSD for artisanal fisheries in Barra Bonita reservoir.

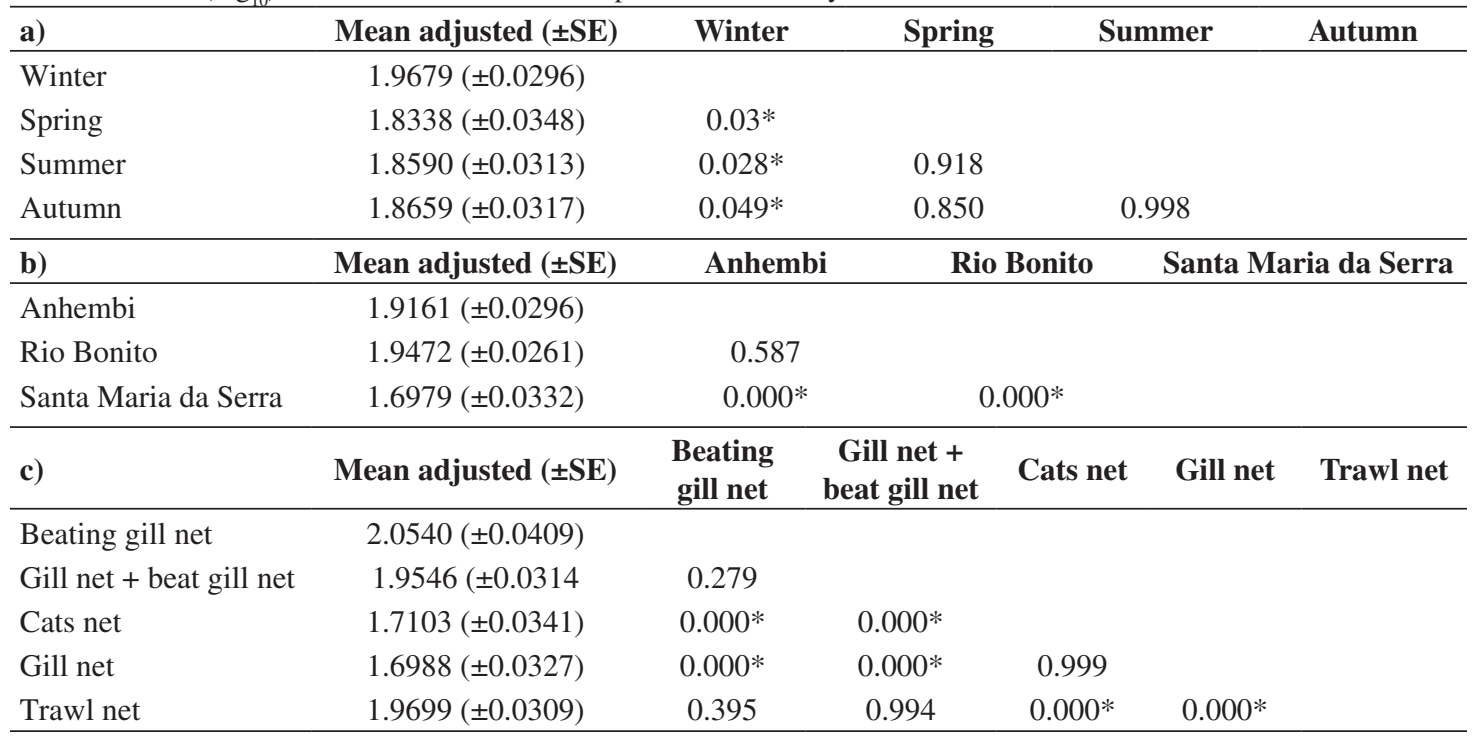

a) season, b) fishing site and c) fishing techniques. *level significance $\mathrm{p}<0.05$.

is uncertain, whether by stocking process or escapements from free-fishing farm, it is believed that the increased eutrophication of the reservoir allowed the proliferation and increase of biomass of the species. Thus, the use of appropriate techniques by fishers made the Nile tilapia the main fish caught and high biomass.

Nile tilapia are the dominant fish in many Brazilian reservoirs and lakes, such as northeastern dams (Paiva et al., 1994), the Pampulha Lagoon (Alvares et al., 2000), the Billings Reservoir (Minte-Vera and Petrere Junior, 2000) and the Paranoá Lake (Petrere Junior et al., 2006; Walter and Petrere Junior, 2007). These reservoirs are all characterised as eutrophic, supporting the hypothesis that eutrophication (or hypereutrophication as in Barra Bonita Reservoir) favours the proliferation of this species. Minte-Vera and Petrere (2000), supported by Fernando and Holčík (1991), mention other factors, in addition to eutrophication, to explain the dominance of the Nile tilapia in the Billings Reservoir, such as their high reproductive potential, capacity to feed effectively on the phytoplankton present, and low predation pressure. Duponchelle et al. (2000) also mention these features to explain the successful colonization by this species of reservoirs in Cotê d'Ivoire. It is probable that these characteristics have also contributed to the proliferation and dominance of this species in the Barra Bonita Reservoir.

The Nile tilapia also predominates in the catches of artisanal fisheries in eutrophic reservoirs and lakes in other parts of the world such as: Southeast Asia, where it is heavily stocked into lakes and reservoirs (Nissanka et al., 2000; Amarasinghe, 2002; De Silva et al., 2004); Cotê d'Ivoire (Duponchelle et al., 2000); Uganda (Bwanika et al., 2004); Lake Victoria (Njiru et al., 2004); Colombia (Cala and Bernal, 1997); Cuba (Averhoff, 1999); and Nicaragua (McCrary et al., 2007). It is clear that eutrophication of water bodies has been an important factor favoring the successful establishment of Nile tilapia elsewhere as well as in Brazilian reservoirs.

On the basis of a daily productivity of $11.11 \mathrm{~kg} / \mathrm{ha}^{-1} / \mathrm{dia}^{-1}$, a CPUE of $62.4 \mathrm{~kg} / \mathrm{fisher}^{-1} / \mathrm{day}^{-1}$, 450 fishers (as estimated by David et al., 2006), and 240 days of fishing per year (excluding Saturday and Sunday), it is possible to estimate the annual yield of the Barra Bonita Reservoir fishery at about $240.0 \mathrm{~kg} / \mathrm{ha}^{-1} / \mathrm{year}^{-1}$. This is higher than the $9.39 \mathrm{~kg} / \mathrm{ha}^{-1} / \mathrm{year}^{-1}$, CPUE $40.4 \mathrm{~kg} / \mathrm{fisher}^{-1} / \mathrm{day}^{-1}$ reported for the reservoir in the 1990s (Torloni et al., 1993) when "corvine" was the main fishery, and the $9.83 \mathrm{~kg} / \mathrm{ha}^{-1} / \mathrm{year}^{-1}$, CPUE of $58.3 \mathrm{~kg} / \mathrm{fisher}^{-1} / \mathrm{day}^{-1}$ in the early 2000s (Eco, 2001) when the Nile tilapia began to predominate in the fishery. Our results showed a substantial increase in the yield of the fishery, but a less marked increase in CPUE. Although the productivity of the fishery increased greatly, this was not reflected in the CPUE values since the number of fishers increased from 30 in 1990s (Torloni et al., 1993) to 450 today (David et al., 2006; Maruyama et al., 2009). Comparing productivity values and the CPUE found in this study with other Brazilian reservoirs, Barra Bonita Reservoir appears to be one of the most productive reservoirs in Brazil, surpassed only by some dams in the northeast region and the Pampulha Lagoon (Table 7). Overall, Brazilian reservoirs have low fishery yields compared to other tropical reservoirs (Jackson and Marmulla, 2001) and possible reasons include low primary productivities, lack of species adapted to lake environments, long food chains, inappropriate fishing techniques and legislation, low fishing effort, and high numbers of piscivores (Fernando and Holćik, 1982; Gomes and Miranda, 2001; Gomes et al., 2002; Agostinho et al., 2007). The eutrophic (or hypereutrophic) reservoirs with high fishery yields are the exceptions (Table 7). These reservoirs are characterised by high primary production, 
Table 7. Yeild by artisanal fisheries in some Brazilian reservoir.

\begin{tabular}{|c|c|c|c|c|}
\hline Reservoir & 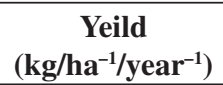 & $\begin{array}{c}\text { CPUE } \\
\left(\mathrm{kg}^{\prime} \text { fisher }^{-1} / \text { day }^{-1}\right)\end{array}$ & Fish main & Reference \\
\hline Tucuruí & 18.0 & 4.7 & $\begin{array}{c}\text { tucunaré, } \\
\text { corvina,mapará }\end{array}$ & $\begin{array}{c}\text { Franco de Camargo and } \\
\text { Petrere Junior (2004) }\end{array}$ \\
\hline Dams in the Northeast* & $18.0-667.0$ & - & Nile tilapia ${ }^{2}$ & Paiva et al. (1994) \\
\hline Três Marias & 6.2 & 13.0 & $\begin{array}{l}\text { Piau três pinta, } \\
\text { Tucunuré }^{2}, \text { corvina }^{2}\end{array}$ & Sato and Sampaio (2006) \\
\hline Billings* & 63.0 & 16.7 & Nile tilapia ${ }^{2}$ & $\begin{array}{c}\text { Minte-Vera and Petrere } \\
\text { Junior }(2000)\end{array}$ \\
\hline Barra Bonita* & $240.0^{1}$ & 62.4 & Nile tilápia ${ }^{2}$ & This paper \\
\hline Barra Bonita & 9.39 & 40.4 & corvina & Torloni et al. (1993) \\
\hline Barra Bonita & 9.83 & 58.3 & Nile tilápia & $\operatorname{Eco}(2001)$ \\
\hline Ibitinga & 6.1 & 26.1 & mandi catfish & $\operatorname{Eco}(2001)$ \\
\hline Promissão & 5.6 & 33.6 & corvina $^{2}$ & Eco (2001) \\
\hline Nova Avanhandava & 3.5 & 35.1 & corvina $^{2}$ & $\operatorname{Eco}(2001)$ \\
\hline Três Irmãos & 2.0 & - & - & CESP (1998) \\
\hline Jurumirim & 15.6 & 10.5 & traíra & $\begin{array}{c}\text { Novaes and Carvalho } \\
\text { (2009) }\end{array}$ \\
\hline Água Vermelha & 2.1 & 28.8 & mandi catfish & Eco (2001) \\
\hline Jupiá & 3.7 & - & mandi catfish & CESP (1998) \\
\hline Ilha Solteira & 1.5 & - & pearl cichlid & CESP (1998) \\
\hline Itaipu & 12.0 & 11.2 & mapará $^{2}$, corvina $^{2}$ & Agostinho et al. (2008) \\
\hline Salto Santiago & 1.1 & 17.5 & lambaris & Okada et al. (1997) \\
\hline Salto Osório & 4.9 & 9,7 & lambaris & Okada et al. (1997) \\
\hline Lake Paranoá* & 39.0 & - & Nilo tilapia $^{2}$ & $\begin{array}{l}\text { Walter and Petrere Junior } \\
\text { (2007) }\end{array}$ \\
\hline Lake Pampulha* & 685.9 & 4.6 & Nile tilapia $^{2}$ & Álvares et al. (2000) \\
\hline
\end{tabular}

*Eutrophic reservoirs; ${ }^{1}$ Estimated yield considering CPUE $62.4 \mathrm{~kg} / \mathrm{fisher}^{-1} / \mathrm{day}^{-1}$ and 240 fishing day per year; ${ }^{2}$ Introduced species exotic and /or allochthonous.

the presence of species adapted to lentic environments the exotic Nile tilapia, low species richness, and relatively few dominant species, and, perhaps for these reasons, these reservoirs are the most productive in Brazil. This suggests that the combination of high primary production due to artificial eutrophication, and the presence of Nile tilapia, has increased the fishery yield in Brazilian lakes and reservoirs. However, the introduction of exotic species and artificial eutrophication cannot be recommended as practices to increase fishery yields. The collateral environmental damage, leads to water quality too poor for leisure use and human consumption, the risk of local extinction of endemic animal and plant species, and the possibility that the fishery may produce fish unsuitable for human consumption.

\subsection{Fishing strategies}

Five fishing techniques were identified in the reservoir: three active techniques, i) trawl net, ii) beating gill net and iii) cast net; one passive technique, iv) gill net; and v) a mixture of active and passive techniques. A correspondence analysis (DCA) distinguished between the active and passive techniques in relation to the biomass of fish caught. The active techniques were used by artisanal fishers to catch Nile tilapia. As mentioned previously, the cast net technique and, especially, the beating gill net technique, have been successfully used to catch Nile tilapia in other Brazilian reservoirs (Câmara et al., 1998; Minte-Vera and Petrere Junior, 2000). The beating gill net technique was probably introduced to the Barra Bonita fishery by fishers from the Billings Reservoir, which is about $300 \mathrm{~km}$ from Barra Bonita. Many fishers from the Billings Reservoir stopped fishing there because of increases in local urban violence, such as theft (Petrere Junior et al., 2006). Some of these fishers currently live in camps on the banks of the Barra Bonita Reservoir, where they continue the fishing techniques they used previously. A third active fishing technique, the trawl net, has been successfully used to catch Nile tilapia. This technique is similar to the trawl net technique used in marine fishing and there is no evidence as to when and how it was introduced to the reservoir. This technique was used in Rio Bonito, where the environmental characteristics, shallow water, fewer snags and the presence of a marginal area where the fishers can beach the trawl net to collect the netted fish, favor its use. The passive gill net technique used was mainly by the 
fishers at Ponte Santa Maria da Serra, where other types of fish, such as Leporinus spp. ("piaus"), Hoplias malabaricus ("traira"), Plagioscion squamosissimus ("corvina"), Astyanax altiparanae, Astyanax fasciatum, Cyphocarax modestus, Steindachinerina insculpta ("lambaris"), and especially Triportheus signatus ("sardinha") and Pimilodus maculates ("mandi"), were caught beside lower numbers of Nile tilapia. Gill nets were successfully used in other reservoirs to catch "mandi", Prochilodus lineatus ("curimbata"), catfish and others (Castro and Begossi, 1995; Agostinho et al., 2007). The mixed technique of gill net + beating gill net was used by fishers from Anhembi and Rio Bonito, but for different purposes. Fishers at Rio Bonito set their gill nets in the late afternoon to catch tilapias. In the morning, when the fishers left to fish using the beating gill net technique, they collected the gill nets and thus maximised their catch of tilapia by using gill nets in the evening and beating gill nets in the morning. At Anhembi, the gill nets were also set in the late afternoon, but to catch "cascudo" and "curimbatá" during the night. After collecting the gill nets in the morning, the fishers used the beating gill net technique to catch Nile tilapia.

An important aspect of a fishing strategy is choosing the right time of day for each technique. At Santa Maria da Serra gill nets were only used at night while beating gill nets, trawl nets and cast nests were used at Anhembi and Rio Bonito in the morning and afternoon. These differences probably reflected the species composition of the fisheries at each location studied.

Of the five fishing techniques indentified at the Barra Bonita Reservoir, only two are legal under Brazilian law, the gill net and cast net (Instrução Normativa do Ministério do Meio Ambiente $\left.n^{\circ} 36,2004\right)$. We also note that artisanal fishing continues unabated during the "piracema" period (November to February) when fishing activity is prohibited in the Barra Bonita Reservoir.

\subsection{ANCOVA}

The results of the ANCOVA showed that the factors (fishing technique, fishing location and season) all influenced the catch. We hypothesise that the different effects of fishing location and fishing technique reflect the differences in the species targeted by the different fisheries. The fishers from Rio Bonito and Anhembi focused on catching Nile tilapia, mainly using active techniques, which are efficient for this species (see the results of the DCA). Another feature of active fishing techniques is the fact that fishers can maximise their daily catch by exploring for sites with high success and quickly abandoning those where catches are low. The low catch rates at Ponte Santa Maria da Serra may be due to lower fish abundance in this stretch of the reservoir, especially Nile tilapia, as well as the fishing techniques adopted by the fishers. At Ponte Santa Maria da Serra, fishers used only gill nets, which, as mentioned, are not an effective technique for catching tilapias, although they are effective for other fish, such as "lambari”, "corvina”, "traíra", Leporinus spp. ("piaus"), "mandi catfish" and "sardinha", which were caught in abundance at Ponte Santa Maria da Serra.

The winter was statistically the most productive season in the Barra Bonita Reservoir. Other studies of fishing in Brazilian rivers and reservoirs have shown seasonality in catches, with drops in productivity mainly due to declines in fish abundance in certain seasons (Silvano and Begossi, 2001; Novaes and Carvalho, 2009; Maruyama et al., 2009). In the Barra Bonita Reservoir, the seasonal water cycle may be another factor influencing the high winter catches. The highest water levels were observed during the winter months and, according to the fishers interviewed, high water levels increase the efficiency of the fishing techniques used, especially trawl nets and beating gill nets, because it increases the area of low water depth at the reservoir shore making capture of Nile tilapia easier.

Our results show that the artisanal fishery in the Barra Bonita Reservoir is focused on the exotic Nile tilapia and, in common with other Brazilian eutrophic reservoirs, consequently supports a highly productive fishery. The eutrophication of the reservoir, and the consequent decrease in water quality and low oxygen content, appears to favor the proliferation of a self-supporting population of Nile tilapia and allows this species to support a highly productive artisanal fishery. The other important factor producing high fishery yields was the substitution of passive fishing techniques, such as gill nets, by active techniques better suited to Nile tilapia capture (beating gill net, cast net and trawl net fishing).

Acknowledgements - The first author is grateful to the post-graduation programme and Department of Morphology, the Universidade Estadual Paulista - Campus Botucatu, for supporting this study, and to the Brazilian government for a scholarship. We thank the team, technicians and students, of the laboratory of fish ecology, for their help at all stages of the work. We thank Dr. Rodrigo Silva da Costa and Dr. Rodrigo Fernandes for their help with the statistical analyses.

\section{References}

AGOSTINHO, AA., GOMES, LC. and PELICICE, FM., 2007. Ecologia e manejo de recursos pesqueiros em reservatórios do Brasil. Maringá: Eduem. 501 p.

AGOSTINHO, AA., PELICICE, FM. and GOMES, LC., 2008. Dam and the fish fauna of the Neotropical region: impacts and management related to diversity and fisheries. Brazilian Journal of Biology, vol. 68, no. 4, Suppl., p. 1119-1132. http://dx.doi. org/10.1590/S1519-69842008000500019

AGOSTINHO, AA., THOMAZ, SM. and GOMES, LC., 2005. Conservation of the biodiversity of Brazil's inland waters. Conservation Biology, vol. 19, no. 3, p. 646-652.

ALVARES, ESS., CANELAS, MAS., COSTA, RG., DIAS, LG., RIBEIRO-MENDES, HN and PINTO-COELHO, RM., 2000. A pesca na represa da Pampulha, Belo Horizonte-MG. Anais do V Simpósio de Ecossistemas Brasileiros: Conservação, vol. 3, no. 109 , p. $375-382$. 
AMARASINGHE, US., 2002. The fishery and population dynamics of Oreochromis mossambicus and Oreochromis niloticus (Oesteichthyes, Cichlidae) in a shallow irrigation in Sri Lanka. Asian Fisheries Science, vol. 15, no. 1, p. 7-20.

AVERHOFF, ORL., 1999. Fish yields in Cuban reservoir and relationships with some morphometric and edaphic parameters. Lakes \& Reservoir: Research and Management, vol. 4, no. 1-2, p. $75-83$.

BARRELLA, W. and PETRERE JUNIOR, M., 2003. Fish community alterations due to pollution and damming in Tietê and Paranapanema rivers (Brazil). River Research and Applications, vol. 19 , no. 1, p. 59-76.

BENNEMANN, ST., CARPA, LG., GALVES, W. and SHIBATTA, OA., 2006. Dinâmica trófica de Plagiosgion squamosissimus (Perciformes, Scieanidae) em trechos de influência da represa Capivara (rio Paranapanema e Tibagi). Iheringia Série Zoologia, vol. 96, no.1, p. 115-119.

BWANIKA, GN., MAKANGA, B., KIZITO, Y., CHAPMAN, LJ. and BALIRWA, J., 2004. Observations on the biology of Nile tilápia, Oreochromis niloticus L., in two Ugandan crater lakes. African Journal of Ecology, vol. 42, suppl. 1, p. 93-111. http:// dx.doi.org/10.1111/j.1365-2028.2004.00468.x

CALA, P. and BERNAL, G., 1997. Ecologia y adaptaciones de la tilapia nilotica (Oreochromis niloticus) en ambientes naturales - Caso embalse de Betania y cienaga de chilloa, sistema del rio Magdalena, Colômbia. DAHLIA Revista Associação Colombina de Ictiologia, vol. 2, no. 1, p. 3-29.

CÂMARA, JJC., SANTOS, RA., CAMPOS, EC. and BARBOSA, JM., 1988. Pesca de batida: um método eficiente para a captura de tilápias preta e do Nilo, utilizado na represa de Marimbondo, Rio Grande, limite centro-oeste do Estado de São Paulo. Boletim Técnico do Instituto de Pesca, no. 11, 12 p.

CARVALHO, ED., BRITTO, SGC. and ORSI, ML., 2005. O panorama das introduções de peixes na bacia hidrográfica do rio Paranapanema, Alto Paraná, Brasil. In ROCHA, O., ESPÍNDOLA, ELG., FENERICH-VERANI, N., VERANI, JR. and REITZLER, AC. (Org.). Espécies invasoras em águas doces - estudo de caso e propostas de manejo. São Carlos: Editora da Universidade São Carlos. p. 253-274.

CASTRO, F. and BEGOSSI, A., 1995. Ecology of fishing on the Grande River (Brazil): technology and territorial rights. Fisheries Research, vol. 23, no. 3-4, p. 361-373. http://dx.doi. org/10.1016/0165-7836(94)00343-U

Companhia Elétrica de São Paulo - CESP, 1998. Conservação e manejo nos reservatórios: limnologia, ictiologia e pesca. São Paulo: CESP, Departamento de Estudos e Planejamento Ambiental. p. 166. Série Divulgação e Informação.

DAVID, GS., CARVALHO, ED., NOVAES, JLC. and BIONDI, GF., 2006. A tilápia do Tietê: Desafios e contradições da pesca artesanal de tilápias nos reservatórios hipertróficos do médio rio Tietê. Panorama da aqüicultura, vol. 16, no. 97, p. 24-27.

DE SILVA, SS., SUBASINGHE, RP., BARTLEY, DM. and LOWTHER, A., 2004. Tilapias as alien aquatics in the Asia and the Pacific: a review. FAO Fisheries Technical Paper, vol. 453, p. 65.

DUPONCHELLE, F., CECCHI, P., CORBIN, D., NUÑEZ, J. and LEGENDRE, M., 2000. Variations in fecundity and eggs size of female Nile tilapia, Oreochromis niloticus, from man-made lakes of Côte d'Ivoire. Environmental Biology of Fishes, vol. 57, no. 2, p. 155-170. http://dx.doi.org/10.1023/A:1007575624937
Eco Consultoria Ambiental e Comercio Ltda., 2001. Limnologia, ictiologia e recursos pesqueiros: período de junho 2000 a julho de 2001. Programas de gestão ambiental AES Tietê S/A. p. 81.

FERNANDO, CH. and HOLČíK, J., 1991. Fish in reservoirs. Internacionale Revue der Gesamten Hydrobiologie, vol. 76, no. 2, p. 149-167. http://dx.doi.org/10.1002/iroh.19910760202

FERRAZ, D., 2002. Tietê: (imagens que o Brasil não vê). Suzano: ONG Rio Tietê. 96 p.

FRANCO DE CAMARGO, SA. and PETRERE JUNIOR, M., 2001. Social and financial aspects of the artisanal fisheries og middle São Francisco River, Minas Gerais, Brazil. Fisheries Management and Ecology, vol. 8, no. 2, p. 163-171. http://dx.doi. org/10.1046/j.1365-2400.2001.00246.x

GOMES, LC. and MIRANDA, LE., 2001. Riverine characteristics dicate composition of fish assemblages and limit fisheries in reservoirs of the Upper Paraná river basin. Regulated River: Research \& Management, vol. 17, no. 1, p. 67-76.

GOMES, LC., MIRANDA, LE. and AGOSTINHO, AA., 2002. Fishery yield relative to chlorophyll $a$ in reservoirs of the Upper Paraná river, Brazil. Fisheries Research, vol. 55, no. 1-3, p. 335340. http://dx.doi.org/10.1016/S0165-7836(01)00278-8

JACKSON, DC. and MARMULLA, G., 2001. The influence of dams on river fisheries. In MARMULLA, G. (Org.). Dam, fihs and fisheries: Opportunities, challenges and conflict resolution. Rome: FAO Fisheries Department. p. 1-44.

LOWE-McCONNELL, RH., 1987. Ecological studies in tropical fish communities. Cambridge University Press. 382 p.

LUDWIG, JA. and REYNOLDS, JF., 1988. Statistical Ecology: a primer on method and computing. Wiley. $337 \mathrm{p}$.

MARUYAMA, LS., CASTRO, PG. and PAIVA, P., 2009. Pesca artesanal no Médio e Baixo rio Tietê, São Paulo, Brasil: Aspectos estruturais e socioeconômicos. Boletim do Instituto de Pesca, vol. 35 , no. 1 , p. 61-81.

MINGOTE, SA., 2005. Análise de dados através de métodos de estatística multivariada: uma abordagem aplicada. Belo Horizonte: Editora UFMG. 297 p.

MINTE-VERA, CV. and PETRERE JUNIOR, M., 2000. Artisanal fisheries in urban reservoirs: a case study from Brazil (Billings Reservoir, São Paulo metropolitan region). Fisheries Management and Ecology, vol. 7, no. 6, p. 537-549. http://dx.doi.org/10.1046/ j.1365-2400.2000.00218.x

McCRARY, JK., MURPHY, BR., STAUFFER JUNIOR, JR. and HENDRIX, SS., 2007. Tilapia (Teleostei: Cichlidae) status in Nicaraguan natural waters. Environmental Biology of Fishes, vol. 80 , no. 1 , p. 78-107.

NISSANKA, C., AMARASINGHE, US and DE SILVA, SS., 2000. Yield predictive models for Sri Lankan reservoir fisheries. Fisheries Management and Ecology, vol. 7, no. 5, p. 425-436. http://dx.doi. org/10.1046/j.1365-2400.2000.00212.x

NJIRU, M., OKEYO-OWUOR, JB., MUCHIRI, M. and COWX, IG., 2004. Shifts in the food of Nile tilapia, Oreochromis niloticus (L.) in Lake Victoria, Kenya. African Journal of Ecology, vol. 42, no. 3, p. 163-170. http://dx.doi.org/10.1111/j.1365-2028.2004.00503.x

NOVAES, JLC. and CARVALHO, ED., 2009. Recursos pesqueiros oriundos da pesca artesanal no reservatório de Jurumirim, Rio Paranapanema, Alto Paraná, Brasil. Boletim do Instituto de Pesca, vol. 35 , no. 4 , p. 553-565. 
OKADA, EK., GREGORIS, J., AGOSTINHO, AA. and GOMES, LC., 1997. Diagnóstico da pesca profissional em dois reservatórios do rio Iguaçu. In AGOSTINHO, AA. and GOMES, LC. (Org.). Reservatório de Segredo: bases ecológicas para o manejo. Maringá: Eduem. p. 293-318.

PAIVA, MP., PETRERE JUNIOR, M., PETENATE, AJ. and NEPOMUCENO, FH., 1994. Relationship between the number of predatory of species and fish yield in large North-eastern Brazilian reservoirs. In COWX, IG. (Org.) Rehabiliation of Freshwater Fisheries. London: Fishing News Books. p. 120-129.

PEREIRA, JMA., PETRERE JUNIOR, M. and RIBEIRO-FILHO, RA., 2008. Angling sport fishing in Lobo-Broa reservoir (Itirapina, SP, Brazil). Brazilian Journal of Biology, vol. 68, no. 4, p. 721-731. http://dx.doi.org/10.1590/S1519-69842008000400006

PETESSE, ML., PETRERE JUNIOR, M. and SPIGOLON, RJ., 2007. The hydraulic management of the Barra Bonita reservoir (SP, Brazil) as a factor influencing the temporal secession of its fish community. Brazilian Journal of Biology, vol. 67, no. 3, p. 433-445. http://dx.doi.org/10.1590/S1519-69842007000300008

PETRERE JUNIOR, M.,1978. Pesca e esforço no Estado do Amazonas. I. Esforço e captura por unidade de esforço. Acta Amazonica, vol. 8, no. 3, p. 439-454.

-, 1996. Fisheries in large tropical reservoirs in South America. Lakes \& Reservoirs: Research and Management, vol. 2, no. 1-2, p. 111-133. http://dx.doi.org/10.1111/j.1440-1770.1996.tb00054.x

PETRERE JUNIOR, M.,GIACOMINI, HC. and DE MARCO JUNIOR, P., 2010. Catch-per-unit-effort: which estimator is best? Brazilian Journal of Biology, vol. 70, no. 3, p. 483-491. http:// dx.doi.org/10.1590/S1519-69842010005000010

PETRERE JUNIOR, M., WALTER, T. and MINTE-VERA, CV., 2006. Income evaluation of small - scale fishers in two Brazilian urban reservoir: Represa Billings (SP) and Lago Paranoá (DF). Brazilian Journal of Biology, vol. 66, no. 3, p. 817-828.
QUINN, GP. and KEOUGH, MJ., 2002. Experimental design and data analysis for biologists. New York: Cambridge University Press. $537 \mathrm{p}$

SATO, Y. and SAMPAIO, EV., 2006. A ictiofauna da região do Alto São Frascisco, com ênfase no reservatório de Três Marias, Minas. In NOGUEIRA, MG., HENRY, R. and JORCIN, A. (Org.). Ecologia de reservatórios; Impactos potenciais, ações de manejo e sistema em cascata. São Carlos: Editora RiMA. p. 251-274.

SILVALNO, RAM. and BEGOSSI, A., 2001. Seasonal dynamics of fishery at the Piracicaba river (Brazil). Fisheries Research, vol. 51, no. 1, p. 69-86. http://dx.doi.org/10.1016/S0165-7836(00)00229-0

STRAŠKRABA, M. and TUNDISI, JG., 2000. Diretrizes para o gerenciamento de lagos: Gerenciamento da qualidade da água de represas. São Carlos: ILEC. 280 p. Série Gerenciamento da qualidade da água de represas.

TORLONI, CEC., CORRÊA, ARA., CARVALHO JUNIOR, AA., SANTOS, JJV., GONÇALVES, JL., GERETO, EJ., CRUZ, JA., MOREIRA, JA., SILVA, DC., DEUS, EF. and FERREIRA, AS., 1993. Produção pesqueira e composição das capturas em reservatórios sob a concessão da CESP nos rios Tietê, Paraná e Grande no período de 1986 a 1991. São Paulo: CESP, Departamento de Estudos e Planejamento Ambiental. 73 p. Série Produção Pesqueira, no. 001.

TUNDISI, JG., MATSUMURA-TUNDISI, T. and ABE, DS., 2008. The ecological dynamcs of Barra Bonita (Tietê River, SP, Brasil) reservoir: implications for its biodiversity. Brazilian Journal of Biology, vol. 68, no 4 suppl., p. 1079-1098. http://dx.doi. org/10.1590/S1519-69842008000500015

WALTER, T. and PETRERE JUNIOR, M., 2007. The small-scale urban reservoir fisheries of Lago Paranoá, Brasília, DF, Brazil. Brazilian Journal of Biology, vol. 67, no. 1, p. 9-21. http://dx.doi. org/10.1590/S1519-69842007000100003

ZAR, JH., 1996. Biostatistical analysis. New Jersey: PrenticeHall. 662 p. 